\title{
Social Justice: Pushing Past Boundaries in Graduate Training
}

\author{
Peggy Brady-Amoon, Nita Makhija, Vasudev Dixit, and Jonathan Dator
}

Seton Hall University

\begin{abstract}
This article explores definitions and integration of social justice in graduate training in counseling and psychology. We examine both the professional literature and our own process in pushing past curricular and administrative boundaries by establishing an extra- or co-curricular component to graduate training that supports the further infusion of social justice principles in graduate training. We conclude with a call for further dialogue and action.
\end{abstract}

Keywords. social justice, counseling, psychology, graduate training, extracurricular

\section{Introduction}

This article explores the integration of social justice in graduate training in counseling and counseling psychology. In so doing, it offers options for extending social justice beyond a designated course, more extensive curricular infusion, and the application of social justice in recruitment, retention, and other traditional program elements (Talleyrand, Chung, \& Bemak, 2006). Beginning with an exploration of the ways in which social justice has been defined and operationalized within counseling and psychology, we examine both the professional literature and our own process, as faculty and students in counseling and counseling psychology, in establishing a campus-based chapter of Counselors for Social Justice (CSJ) and Psychologists for Social Responsibility (PsySR). We conclude with a call for further dialogue and action to further infuse social justice principles and practice in graduate training in counseling and psychology.

\section{Social justice in counseling and psychology}

Social justice and social responsibility are associated with counseling, counseling psychology, and many other specialty areas within psychology (Constantine, Hage, Kindaichi, \& Bryant, 
2007; Fouad, Gerstein, \& Toporek, 2006; Palmer, 2004; Rutherford, Cherry, \& Unger, 2011). Moreover, social justice is foundational to counseling (Kiselica \& Robinson, 2001) and counseling psychology (Toporek, Gerstein, Fouad, Roysircar, \& Israel, 2006), sister disciplines rooted in the humanistic tradition that emphasize human wellness, strengths, and contextual considerations (Goodyear, 2000; Remley \& Herlihy, 2010). To illustrate, Frank Parsons and Carl Rogers, considered founders of counseling and counseling psychology, were well known social justice advocates and role models (Kiselica \& Robinson, 2001; Munley, Duncan, McDonnell, \& Sauer, 2004). Building on this history, counselors and counseling psychologists have been at the forefront of feminist (Evans, Kincade, Marbley, \& Seem, 2005), multicultural (Sue, Arredondo, \& McDavis, 1992), and other movements within counseling and psychology to address oppression (see, for example, Smith, Foley, \& Chaney, 2008).

Counseling psychologists are not the only psychologists to have a demonstrated interest in and commitment to social justice and social responsibility. The Society for the Psychological Study of Social Issues (SPSSI), founded in 1936 (Rutherford et al., 2011), and Psychologists for Social Responsibility (PsySR, 2011), founded in 1982, are two groups that also have a long-standing historical commitment to social justice. These movements have also contributed to the increased awareness of social justice and infusion of same throughout the graduate training curriculum.

Both professions' current commitment to social justice is evident in their public documents. For example, the American Counseling Association Code of Ethics (ACA, 2005), in which multicultural/diversity competence is infused, calls upon counselors to promote changes that improve the quality of life for individuals and groups and remove potential barriers to the receipt of appropriate services. Similarly, the Ethical Principles of Psychologists and Code of Conduct of the American Psychological Association (APA, 2010) exhorts psychologists to promote justice and demonstrate respect for all people. More specific to counseling psychology, the recently adopted Practice Guidelines for Professional Training (CCPTP, ACCTA, \& SCP, 2009; Miville et al., 2009) integrate and extend a large body of work supporting the infusion of multicultural and social justice competencies in graduate training.

Given the nexus among counseling, psychology, and social justice (Ali, Liu, Mahmood, \& Arguello, 2008; Crethar \& Ratts, n.d.; Goodman, Liang, Helms, Latta, Sparks, \& Weintraub, 2004), we were somewhat surprised that there is no common agreement as to what social responsibility or social justice entails. Social justice has been conceptualized as the meeting of everyone's basic needs (Smith, 2003 as cited in Goodman et al., 2004), as the culmination of feminism and multiculturalism (Crethar, Rivera, \& Nash, 2008), as advocacy (Ratts, Toporek, \& Lewis, 2010), and as work to attain myriad specific goals (Rutherford et al., 2011; PsySR, 2011). Social justice has also been conceptualized as research and professional action to assure opportunities and access for historically marginalized people (Goodman et al., 2004). Synthesizing these approaches, Counselors for Social Justice (CSJ, 2011) defines social justice as work with and for clients to promote human development while the American Counseling Association (ACA) Advocacy Competencies (Lewis, Arnold, House, \& Toporek, 2002; Ratts et al., 2010) takes this one step further, positing a continuum of social justice work, ranging from advocacy to social action and from action for clients to action with clients. Given the myriad of ways that social justice and social responsibility are conceptualized, it is clear that social justice and social responsibility in counseling and psychology are not monolithic concepts. However, 
one commonality is a focus on the counselor or psychologist engaging in the process of change throughout his or her training in multiple ways and at various levels of society.

\section{Fostering social justice through reflection and reflexivity}

Throughout the development of this article, which was inspired by a shared interest in social justice in graduate training, we were reminded that discussions with colleagues are often simultaneously helpful and challenging. We found, for example, that informal discussions, particularly those that take place co- or extra-curricularly, have potential to promote insight, including recognition of some of the ways in which unexamined and unchallenged power and privilege reinforces the marginalization of disenfranchised persons and communities (Goodman et al., 2004; McDowell \& Hernandez, 2010). It also became apparent to us that truly collaborative - and client empowering - work (Goodman et al., 2004; Freire, 1970) requires ongoing commitment to critical analysis and feedback from others, both formal and informal (Hurtado, 2010).

In addition to formal training opportunities in the classroom (Odegard \& Vereen, 2010; Steele, 2008) and through supervised field work (Glosoff \& Durham, 2010; Burnes \& Manese, 2008), we submit that support for reflective practice is essential for counselors and psychologists interested in understanding and working for social justice. Through reflection, students, trainees, and professionals are challenged to critically examine their own assumptions, values, and biases, and to challenge those that limit or impede our and others' potential. As an individually-oriented process, reflection is limited. However, reflexivity or reflection that encourages the exploration of participants' "multiple subjectivities" (Hurtado, 2010, p. 34), privileges, and identities in conjunction with others (Hurtado, 2010), has more potential for increasing awareness, knowledge, and promoting action (Gilbert \& Sliep, 2009). Given the risks associated with social action (Bemak \& Chung, 2008; D'Andrea \& Daniels, 2010), we submit that co- and extra-curricular organizations that promote shared discourse provide a much needed forum for reflection, reflexivity, and consciousness raising (Enns \& Byars-Winston, 2010).

Consistent with feminist (Brown, 1997), multicultural (D'Andrea \& Daniels, 2012), and multicultural feminist (Enns \& Byars-Winston, 2010; Hurtado, 2010) approaches to counseling and psychology, we employed both reflection and reflexivity as we engaged in an ongoing critical examination of our own role(s) in socially constructed power hierarchies throughout this process. We were particularly interested in the influence of our roles and perceived roles as students and faculty in counseling and counseling psychology in our developing awareness and knowledge, both of which are considered foundational to empowered action, including advocacy (Toporek \& Liu, 2001). Although these conversations - and reflective practice - are often integrated into the curriculum, many students are reluctant to truly engage in this work, particularly when they are concerned that their lack or perceived lack of social justice awareness or skills will put their grades or even continued enrollment in the program at risk. As illustrated by Chung and Bemak's (2012) account of a student who failed an internship course for failing to take action on behalf of students who complained about discrimination, it is not unreasonable for students to be concerned about the risks inherent in exploring ideas that are not consistent with the overall ethos of their training program. 
As such, our experience suggests that extra-curricular organizations such as CSJ and PsySR contribute to establishing a culture of social justice within a training program that goes beyond the classroom. Participating in on-campus chapters of social justice organizations provides students a venue in which to surround themselves with like-minded individuals and allows for informal and collaborative students-faculty interaction. Co- and extra-curricular organizations provide a forum for reflection, reflexivity, and consciousness-raising, often as a prelude to collaborative action and/or advocacy. Furthermore, those who participate in these organizations are showing a commitment to social justice that is not necessarily held by those completing required social justice-based coursework. Joining these organizations signals a desire to learn more fully about and embrace the integration of social justice within one's field of study and take action on these beliefs, as opposed to simply fulfilling curricular requirements.

\section{Social justice training in graduate school education}

Through our collaborative process, that is reflecting on our individual and collective socialized expectations, power, and privilege (Enns \& Byars-Winston, 2010; Hurtado, 2010), we became more aware that the discussion of what social justice means and how it is actualized is a necessary but insufficient conversation. We also became aware that discussions about social justice often occur among and between people who are already advocates for social justice or, at the other extreme, those who are opposed to the incorporation of social justice in their profession. To illustrate the latter, Toporek and Williams (2006) note that Education Directorate of the American Psychological Association (APA) regularly receives letters protesting social justice oriented policy positions (e.g. immigration policy statements); arguing that these positions are outside the scope of the organization and profession.

As counselors and psychologists, we need to move beyond dichotomous thinking to truly consider the association between social justice and our professions. Furthermore, dialogue must include those who are preparing to enter our professions. However, once again, conversations alone are not sufficient; students need opportunities to critically consider the intersection between their personal and professional identities and their evolving definition of social justice, apply what they learn in class, and experience working from a social justice framework in order to fully understand what it entails (Bemak \& Chung, 2011; CSJ, 2011; Miville et al., 2009; O'Brien, Patel, Hensler-McGinnis, \& Kaplan, 2006; Talleyrand et al., 2006).

The integration of multiculturalism in counseling and counseling psychology training programs provides an excellent model for the infusion of social justice into graduate training. In recent years, multicultural counseling and psychology has moved from fringe to mainstream (Goodman et al., 2004; Miville et al., 2009; Toporek, Lewis, \& Crethar, 2006; Vera \& Speight, 2003). Currently, most states require or at least recommend coursework in multicultural counseling and psychology to qualify for, or maintain professional licensure as a counselor or psychologist. Furthermore, many graduate programs have moved beyond simply mandating students to complete a stand-alone course on multicultural topics, to incorporating multiculturalism into all aspects of their training program. This integration allows for students to gain an understanding of how multiculturalism factors into all aspects of their work.

While great strides have been made in incorporating multiculturalism into graduate training, the integration of social justice, resurgent in the late 1990s and early 2000s (Fouad et al., 2006; Helms, 2003; Ponterotto, Casas, Suzuki, \& Alexander, 2010), remains at the periphery. This is 
unfortunate, given the interdependent relationship between multicultural and social justice awareness and competence (Crethar et al., 2008; Goodman et al., 2004; Zalaquett, Foley, Tillotson, Dinsmore, \& Hoff, 2008).

Although exceptions exist (Ali et al., 2008; Bemak \& Chung, 2011; Chung \& Bemak, 2012; Talleyrand et al., 2006; Toporek et al., 2006), it appears that the great majority of graduate training programs discuss social justice abstractly or theoretically without providing students the ability to engage in the necessary reflective preparation to ethically and effectively engage in social justice work during and after their training. We submit that, ideally, the integration of social justice in graduate training would progress from learning about foundational theory and research to supervised practice, in conjunction with formal and informal opportunities for trainees to develop knowledge, awareness, and skills for social justice competency. We were pleased to see this recommendation in the CSJ Code of Ethics (2011), which appears to be the first ethical code to explicitly charge counseling faculty with providing curricular and extracurricular opportunities to engage in the personal dimension of inter-relational reflexivity (Gilbert \& Sliep, 2009).

It is incumbent upon those of us in or aspiring to educational and professional leadership roles to support, both formally and informally, the development of trainees' knowledge and skills in this arena. As discussed previously, Goodman et al. (2004) provide some ideas for the practical integration of social justice into graduate training. These ideas include emphasizing the development of social justice knowledge and skills throughout the curriculum as has been done for the multicultural perspective; reconsidering the weight given to community work in the hiring, promotion, and tenure process; and instituting additional incentives for social justice work. Furthermore, social justice training can take place through the use of service-based learning and community based practicums (Bemak \& Chung, 2011; Talleyrand et al., 2006; Toporek et al., 2006; Vera \& Speight, 2003). These are all important avenues to consider for the infusion of social justice training in graduate curriculum. Overall, the goal of this infusion is to foster social responsibility in future helping professionals.

Although it is necessary to include social justice theory and research in the curriculum, as we learned from the development of the multicultural movement, curricular infusion is not sufficient. The infusion of social justice into the curriculum is helpful in introducing social justice conceptually; however opportunities for reflection, reflexivity, and critical analysis have the potential to serve as catalysts for further development of multicultural and social justice awareness, knowledge, and skills. Furthermore, it is essential to incorporate social justice principles into the organizational culture of the graduate program to provide the necessary organizational support for the development of social justice awareness and skills (D'Andrea \& Daniels, 2010; Zalaquett et al., 2008).

Along these lines, social justice organizations may be conceptualized as an extension of the curriculum. Although classroom experience may introduce social justice from a structured, academic perspective, engaging in extra- or co-curricular activities through a campus-based organization offers the opportunity to translate knowledge gained in the classroom to action in the field. The true value of an organization such as a CSJ or PsySR on-campus chapter is its ability to build a bridge between the classroom and professional practice. This is essential to support the development of helping professionals who are both sensitive and effective in addressing social justice issues. 


\section{Establishing a campus-based chapter of CSJ/PsySR}

Our initial questions revolved around the prerequisites for the integration of social justice and development of a collaborative development/training milieu. We were also interested in ways that faculty members and graduate students could better support each other in the pursuit of developing social justice competence and infusing social justice throughout graduate training. Additionally, we were confronted with the challenge of balancing idealism with the practical realities and full schedules of graduate training and our lives.

One way to foster this dialogue and provide supplemental professional development opportunities is by establishing university chapters of social justice based organizations such as CSJ and PsySR. Consistent with the way in which the national establishment of these organizations suggests that social justice awareness is taking root in professional counseling and psychology, these organizations have the potential for even greater influence when established in graduate training programs.

This understanding led us to the development of a combined student led campus-based chapter of CSJ/PsySR at our university. As discussed, the chapter was developed to augment the training environment, and to provide support for social-justice oriented counselors, psychologists, and graduate students. We also hoped that a student-led organization would provide an opportunity for students and faculty alike to share and develop knowledge and skills in advocacy and other aspects of social action (Toporek et al., 2006).

It is important to note that our local chapter did not develop in a vacuum. It developed from conversations the first author had with other members of the CSJ national membership committee to brainstorm ways to encourage grassroots participation in CSJ. The members of that committee observed that graduate students were often interested in social justice, both theoretically and practically, and that local CSJ chapters might provide an opportunity for students, faculty, alumni, and community members to collaborate and learn with each other.

Given CSJ's association with the American Counseling Association (ACA), the first author began by inviting counseling students and faculty to an inaugural/introductory meeting. Those present at that meeting, counseling students and counseling and counseling psychology faculty, unanimously agreed to invite other interested allies to join - thus expanding the conversation. This invitation was enthusiastically accepted by a small cohort of counseling psychology students so that we believe that we can claim to be the first joint CSJ/PsySR campus-based chapter.

Our progress to date has included a renewed interest in understanding what social justice is and the ways in which counselors and psychologists can integrate a social justice framework into our work and lives. We have had discussions and taken action as individuals and subgroups on issues that concern us. For example, some of us volunteer in the community and others are engaged in professional advocacy work. Consistent with our commitment to an emerging theory of social justice founded on multicultural and feminist principles, the current members of our campus-based chapter of CSJ/PsySR do not take the position that we must all agree; rather we see this organization as a safer place than the formal curriculum to explore issues and 
concerns, including how we are influenced by the social-political-economic context and the ways in which that context influences the people with whom we work. All are welcome in this open, collaborative, peer-led structure. Our CSJ/PsySR chapter decided against a formal leadership structure (e.g. officers or dues). This is working well for us as it offers opportunities for all to participate in the leadership. However, the lack of formal leadership has its pitfalls, one of which is that we are still in the process of adopting a mission statement, consistent with CSJ, PsySR, and the University/departmental context, to which we conceptually agreed about a year ago.

One of the things we have learned through establishing our chapter of CSJ/PsySR is that this type of co- or extracurricular activity makes it easier for like-minded students and faculty to come together for formal and informal discussions regarding social justice. Students who participate in our chapter of CSJ/PsySR often comment that participation facilitates their personal and professional development with others who are committed to integrating social justice principles in their work. We have also found that our CSJ/PsySR chapter provides an additional opportunity for students and faculty to learn from and teach one another, creating an example of the collaborative process that is essential for furthering social justice in counseling and psychology. Lastly, a university-based CSJ/PsySR chapter also permits students to work with like-minded faculty and peers to build a social justice organization and take action on causes they deem significant.

\section{Walking the talk: Turning theory into action/practice}

In parallel with the development of the student-led chapter of CSJ/PsySR, we also used a collaborative process to develop the presentation that inspired this paper. The initial presentation took place at the 2011 PsySR conference in the format of a Participant Idea Exchange (PIE). In this student-generated PIE, we held a discussion with other like-minded individuals involved in graduate training regarding the ways in which social justice is defined and operationalized as well as how it might best be infused, beyond the curriculum and supervised field work, into graduate education. We are grateful to the people who participated and shared their stories, insights, and suggestions with us. That discussion inspired us to encourage others to join this conversation by writing this article.

Throughout the process of developing our ideas and seeking others' perspectives, we have strived to better understand ourselves as people and professionals, each other, and the situational/contextual factors that influence our lives and the lives of the people we are called to serve. Some of the questions we are still considering in the context of the campus-based chapter of CSJ/PsySR include: How do we deal with the challenges of taking "the road less travelled"? What are the social ramifications of speaking up? What is the relationship between learned helplessness (in making systemic changes) and becoming the oppressor (through inaction)? In so doing, we have explored Bemak and Chung's (2008) concept of Nice Counselor Syndrome (NCS), which they define as maintaining harmony and avoiding conflict at the cost of reinforcing inequities and of perpetuating the status quo. Bemak and Chung (2008) posit that many well-meaning counselors avoid social justice work because of real or imagined fears that sometimes manifest as apathy and anger. They also offer several suggestions for overcoming NCS, including training, preparation, and developing and maintaining a support system. We believe that one way to do this is through the establishment social justice-based co- and extra- 
curricular organizations, as these organizations provide a setting in which members can support one another while taking the actions they deem necessary to promote social changes.

In addition to a focus on individual action, the need for social justice action to be orchestrated through professional partnerships has been emphasized in social justice literature (Zalaquett et al., 2008; Bemak \& Chung, 2008). We submit that collaboration with colleagues willing to engage the process of social justice, such as in our CSJ/PsySR chapter, has the potential to alleviate the personal tension that many people experience working towards change. In addition, attending and presenting at conferences on multicultural topics and social justice advocacy, such as the authors did at the 2011 PsySR conference, is another way to tap into supportive and rejuvenating resources.

Furthermore, as discussed above, as conversations about social justice often occur between like-minded individuals; we are aware that more needs to be done to reach people outside the existing professional organizations and disciplinary silos. Therefore, consistent with our evolving understanding of social justice in graduate training, our combined campus-based chapter of CS] and PsySR has moved beyond traditional academic boundaries by encouraging inter-disciplinary dialogue and inviting professionals from disciplines outside of counseling and psychology to join us.

We are still in the process of exploring what a strong student-led chapter of PsySR/CSJ would look like and finding ways to enhance our relatively new campus-based group. As such, a closer look at the context in which our graduate programs and CSJ/PsySR chapter functions is offered next.

\section{Understanding the context}

We are fortunate to be associated with a University that is in a geographic and socio-cultural milieu that promotes the inclusion of diverse perspectives and social justice. The University was founded in 1856 to provide educational opportunities for Catholics, many of whom were materially poor immigrants and children of immigrants, who were often not admitted to other existing institutions of higher education (Quinn, n.d.). This, in conjunction with the Catholic commitment to social justice, is integral to the University's mission and practice. The graduate programs in counseling and counseling psychology are housed in the University's College of Education and Human Services (CEHS). The College's vision statement is to "prepare competent, socially conscious, and reflective professionals" (CEHS, 2009, para 2). Likewise, the programs are situated within a department that is focused on preparing socially conscious counselors and psychologists who are prepared to work in a dynamic, multi-disciplinary environment (Palmer, 2004). We are very much aware that this is fertile ground for infusing social justice within graduate training. We are also aware that many of our peers and colleagues will likely encounter more difficulties that we have encountered and that this is a significant limitation to the suggestions that follow.

\section{A call for further dialogue and action}

Through this process of exploring the incorporation of social justice and social responsibility in graduate training, we have learned that social justice is a dynamic and evolving construct. We also learned that there is no single definition of social justice - or consensus as to whether 
social justice ought to be included in graduate training in counseling and psychology. Our review of the literature, and our reflective and reflexive process as we developed our presentation at PsySR and this manuscript have confirmed our initial shared belief that a comprehensive approach to education and training in social justice that includes voluntary extracurricular opportunities has the potential to enhance graduate training in counseling, counseling psychology, and psychology as a whole. Organizations such as CSJ and PsySR provide opportunities for students, practitioners, and academics to learn from and with each other, network, and share what they learn beyond the curriculum or specific organizational meeting, conference, or publication, thus transforming theory into application.

One of the challenges we have faced in developing this chapter has been navigating the competing priorities of graduate training. Many CSJ/PsySR members and potential members have indicated that they have limited time for what they consider to be "non-essential" activities. We have addressed this by encouraging but not requiring participation and exploring ways of meeting our responsibilities in this expanded context (Toporek \& Williams, 2006). We have also built on our knowledge that person to person communication has historically been shown to be an effective way of sharing knowledge and promoting advocacy (Avery \& Bashir, 2003). We are also aware that counselors and psychologists who engage in this process often develop increased understanding and knowledge. As such, we submit that opportunities to voluntarily engage in extracurricular activities, like those sponsored by a campus-based chapter of CSJ/PsySR, provide a forum to develop community, social justice awareness, knowledge, skills - and options for individual, small group, and collective action. Overall, the process can be mutually beneficial for all involved (Freire, 1970).

Social justice work, especially the type of work that challenges existing power structures, requires courage, commitment, and fortitude (Bemak \& Chung, 2008; D'Andrea \& Daniels, 2010; Kiselica \& Robinson, 2001). Given the concerns that some people have about speaking up, it is clear that one of the best ways to reach a comfort level in speaking up is to join forces with other like-minded people. Regardless of one's status as a faculty member, graduate student, or community member, people who know they have support are more likely to stand up for their beliefs (Tyler, 2010). We have learned that informal and formal dialogue in the context of a supportive graduate training community, including a campus-based chapter of $\mathrm{CSJ} /$ PsySR, promotes social responsibility and the work we choose or are called to do for social justice.

Social justice is not just a way of viewing how things "should" be. Through our reflective practice, we join with those (e.g. Chung \& Bemak, 2012) who suggest that social justice represents the evolution of multiculturalism - the conversion of multicultural awareness, knowledge, and skills into action that results in transformation. Social justice can also be viewed as a force that actively engages the historically accepted and pervasive inequities that prevent all individuals of a society from achieving their potential. This is why social justice action is an endeavor pursuable by anyone. When a person truly embraces the spirit of multiculturalism and feminism, he or she may choose or feel called to become socially responsible and to work for social justice. This may begin by challenging the unspoken assumptions defined by the majority culture that maintain power differentials. By stepping outside of one's comfort zone, and immersing the self in other cultures, it becomes easier to empathize with the unique struggles of those from other backgrounds. Thus, while activists from different fronts may conceptualize 
social justice from different angles, a commitment to social responsibility and social justice begins with personal commitment.

The presence of a chapter of CSJ/PsySR establishes an arena for students' voices to be heard and thoughts to be both shared and discussed. The chapter can provide a springboard for action. Guests can also be invited to share their experiences in social justice. Additionally, a student chapter or organization provides students with the opportunity to combine forces and step up to a more national platform, promoting social justice research and practice at professional conferences. Finally, a chapter creates the necessary structure that must be in place for the long term planning that is necessary for designing and engaging in extracurricular activities that could range from social advocacy at the local or state level (e.g. the Occupy movement) to community outreach events within the local area of the university where the chapter has been established.

We recognize that some people will likely feel more called to social responsibility and social justice than others. Through this process, we also came to recognize that there are many ways, approaches, and venues for living a socially responsible personal and/or professional life. Many of these begin with and are accompanied by reflective and reflexive exploration. As such, we are continuing to dialogue about ways in which we can continue this discussion and more fully incorporate social justice into graduate training - and we welcome your contribution to this dialogue.

\section{Contact information:}

Peggy Brady-Amoon, Ph.D.

Department of Professional Psychology and Family Therapy

Seton Hall University

Email: margaret.brady-amoon@shu.edu

\section{References}

Ali, S, R., Liu, W. M., Mahmood, A, \& Arguello, J. (2008). Social justice and applied psychology: Practical ideas for training the next generation of psychologists. Journal for Social Action in Counseling and Psychology, 1, 1-13.

American Counseling Association. (2005). ACA Code of Ethics. Washington, DC: Author.

American Psychological Association. (2010). Ethical Principles of Psychologists and Code of Conduct: 2010 Amendments.

Retrieved from: http://www.apa.org/ethics/code/index.aspx?item=7\#907

Avery, B., \& Bashir, S. (2003). The road to advocacy - Searching for the rainbow. American Journal of Public Health, 98, 1207-1210. 
Bemak, F., \& Chung, R. C. (2008). New professional roles and advocacy strategies for school counselors: A multicultural/social justice perspective to move beyond nice counselor syndrome. Journal of Counseling \& Development, 86, 372-381.

Bemak, F., \& Chung, R. C. (2011). Applications in social justice counselor training: Classroom without walls. Journal of Humanistic Counseling, 50, 204-219.

Brown, L. S. (1997). Ethics in psychology: Cui bono? In D. Fox \& I. Prilleltensky (Eds.), Critical psychology: An introduction (pp. 51-67). Thousand Oaks, CA: Sage.

Burnes, T. R., \& Manese, J. E. (2008). Social justice in an accredited internship in professional psychology: Answering the call. Training and Education in Professional Psychology, 2, 176-181.doi: 10.1037/1931-3918.2.3.176

Chung, R. \& Bemak, F. (2012). Social justice in counseling: The next step beyond multiculturalism. Thousand Oaks, CA: Sage.

College of Education and Human Services. (2009). Assessment system. Retrieved from http://www.shu.edu/academics/education/upload/CEHSUnitAssessSystem.pdf

Constantine, M. G., Hage, S. M., Kindaichi, M. M., \& Bryant, R. M. (2007). Social justice and multicultural issues: Implications for the practice and training of counselors and counseling psychologists. Journal of Counseling \& Development, 85, 24-29.

Council of Counseling Psychology Training Programs, Association of Counseling Center Training Agencies, \& Society of Counseling Psychology. (2009). Counseling psychology model training values statement addressing diversity. The Counseling Psychologist, 37, 641643. doi: $10.1177 / 0011000009331930$

Counselors for Social Justice. (2010). What is social justice in counseling? Retrieved from http://counselorsforsocialjustice.com/

Counselors for Social Justice. (2011). The Counselors for Social Justice (CSJ) code of ethics. Journal for Social Action in Counseling and Psychology, 3, 1-21.

Crethar, H. C., \& Ratts, M. (n.d.) Why social justice is a counseling concern. Retrieved from http://www.txca.org/images/tca/Template/TXCSJ/Why_social_justice_is_a_counseling_c oncern.pdf

Crethar, H. C., Rivera, E. T., \& Nash, S. (2008). In search of common threads: Linking multicultural, feminist, and social justice counseling paradigms. Journal of Counseling \& Development, 86, 269-278.

D'Andrea, M., \& Daniels, J. (2010). Promoting multiculturalism, democracy, and social justice in organizational settings. A case study. In J. G. Ponterotto, J. M. Casas, L. A. Suzuki, \& C. M. Alexander (Eds.), Handbook of multicultural counseling (3rd ed., pp. 591-602). Thousand Oaks, CA: Sage. 
Enns, C. Z., \& Byars-Winston, A. M. Multicultural feminist theory. In H. Landrine \& N. F. Russo (Eds.), Handbook of diversity in feminist psychology (pp. 367-388). New York: Springer.

Evans, K. M., Kincade, E.A., Marbley, A. F., \& Seem, S. R. (2005). Feminism and feminist therapy: Lessons from the past and hopes for the future. Journal of Counseling \& Development, 83, 269-277.

Fouad, N. A., Gerstein, L. H., \& Toporek, R. L. (2006). Social justice and counseling psychology in context. In R. L. Toporek, L. H. Gerstein, N. A. Fouad, G. Roysircar, \& T. Israel (Eds.), Handbook for social justice in counseling and psychology: Leadership, vision, and action (pp. 1-16). Thousand Oaks, CA: Sage.

Freire, P. (1970/1990). Pedagogy of the oppressed. New York: Continuum.

Gilbert, A., \& Sliep, Y. (2009). Reflexivity in the practice of social action: From self-to interrelational reflexivity. South African Journal of Psychology, 39, 468-479.

Glosoff, H. L., \& Durham, J. C. (2010). Using supervision to prepare social justice counseling advocates. Counselor Education \& Supervision, 50, 116-129.

Goodman, L. A., Liang, B., Helms, J. E., Latta, R. E., Sparks, E., \& Weintraub, S. R. (2004). Training counseling psychologists as social justice agents: Feminist and multicultural principles in action. The Counseling Psychologist, 32, 793-837. doi: $10.1177 / 0011000004268802$

Goodyear, R. K. (2000). An unwarranted escalation of counselor-counseling psychologist professional conflict: Comments on Weinrach, Lustig, Chan, and Thomas (1998). Journal of Counseling \& Development, 78, 103-106.

Helms, J.E. (2003). A pragmatic view of social justice. The Counseling Psychologist, 31, 305313. doi: $10.1177 / 0011000003031003006$

Hurtado, A. (2010). Multiple lenses: Multicultural feminist theory. In H. Landrine \& N. F. Russo (Eds.), Handbook of diversity in feminist psychology (pp. 29-54). New York: Springer.

Kiselica, M. S., \& Robinson, M. (2001). Bringing advocacy counseling to life: The history, issues, and human dramas of social justice work in counseling. Journal of Counseling \& Development, 79, 387-397.

Lewis, J. A., Arnold, M. S., House, R., \& Toporek, R. L. (2002). The ACA advocacy competencies. Retrieved from http://www.counseling.org/Resources/Competencies/Advocacy_Competencies.pdf

McDowell, T., \& Hernandez, P. (2010). Decolonizing academia: Intersectionality, participation, and accountability in family therapy and counseling. Journal of Feminist Family Therapy, 22, 93-111. doi:10.1080/08952831003787834 
Miville, M. L., Duan, C., Nutt, R. L., Waehler, C. A., Suzuki, L., Pistole, C., ...Corpus, M. (2009). Integrating practice guidelines into professional training: Implications for diversity competence. The Counseling Psychologist, 37, 519-563. doi: $10.1177 / 0011000008323651$

Munley, P. H., Duncan, L. E., McDonnell, K. A., \& Sauer, E. M. (2004). Counseling psychology in the United States of America. Counselling Psychology Quarterly, 17, 247-271. doi: $10.1080 / 09515070412331317602$

O'Brien, K. M., Patel, S., Hensler-McGinnis, N., \& Kaplan, J. (2006). Empowering undergraduate students to be agents of social change: An innovative service learning course in counseling psychology. In R. L. Toporek, L. H. Gerstein, N. A. Fouad, G. Roysircar, \& T. Israel (Eds.), Handbook for social justice in counseling psychology. Leadership, vision, and action (pp. 59-76). Thousand Oaks, CA: Sage.

Odegard, M. A., \& Vereen, L. G. (2010). A grounded theory of counselor educators integrating social justice in to their pedagogy. Counselor Education \& Supervision, 50, 130-149.

Palmer, L. K. (2004). The call to social justice: A multidiscipline agenda. The Counseling Psychologist, 32, 879-885. doi: 10.1177/0011000004269278

Psychologists for Social Responsibility. (2011). Retrieved from http://www.psysr.org/

Ponterotto, J. G., Casas, J. M., Suzuki, L. A., \& Alexander, C. M. (Eds.). (2010). Handbook of multicultural counseling (3rd ed.). Thousand Oaks, CA: Sage.

Quinn, D. (n.d.) History of Seton Hall University. Unpublished manuscript, Seton Hall University, South Orange, NJ.

Ratts, M. J. Toporek, R. L., \& Lewis, J. A. (2010). ACA advocacy competencies: A social justice framework for counselors. Alexandria, VA: American Counseling Association.

Remley, T. P., \& Herlihy, B. (2010). Ethical, legal, and professional issues in counseling (3rd ed.). Upper Saddle River, NJ: Prentice Hall.

Rutherford, A., Cherry, F., \& Unger, R. (2011). "Society very definitely needs our aid": Reflecting on SPSSI in history. Journal of Social Issues, 67, 1-7. doi:10.1111/j.15404560.2010.01678.x

Smith, L., Foley, P. F., \& Chaney, M. P. (2008). Addressing classism, abelism, and heterosexism in counselor education. Journal of Counseling \& Development, 86, 303-309

Steele, J. M. (2008). Preparing counselors to advocate for social justice: A liberation model. Counselor Education \& Supervision, 48, 74-85.

Sue, D. W., Arredondo, P., \& McDavis, R. J. (1992). Multicultural counseling competencies and standards: A call to the profession. Journal of Multicultural Counseling and Development, $20,64-88$. 
Talleyrand, R. M., Chung, C. C., \& Bemak, F. (2006). Incorporating social justice in counselor training programs: A case example. In R. L. Toporek, L. H. Gerstein, N. A. Fouad, G. Roysircar, \& T. Israel (Eds.), Handbook for social justice in counseling psychology. Leadership, vision, and action (pp. 44-58). Thousand Oaks, CA: Sage.

Toporek, R. L., Gerstein, L. H., Fouad, N. A., Roysircar, G., \& Israel, T. (2006). Handbook for social justice in counseling psychology. Leadership, vision, and action. Thousand Oaks, CA: Sage.

Toporek, R., Lewis, J., and Crethar, H. (2009). Promoting systemic change through the ACA Advocacy Competencies. Journal of Counseling \& Development, 87, 260-268.

Toporek, R. L., \& Liu, W. M. (2001). Advocacy in counseling: Addressing issues of race, class, and gender oppression. In D. B. Pope-Davis and H. L. K. Coleman (Eds.), The intersection of race, class, and gender in counseling psychology (pp. 385-416). Thousand Oaks, CA: Sage. .

Toporek, R. L., \& Williams, R. A. (2006). Ethics and professional issues related to the practice of social justice in counseling psychology. In R. L. Toporek, L. H. Gerstein, N. A. Fouad, G. Roysircar, \& T. Israel (Eds.), Handbook for social justice in counseling psychology. Leadership, vision, and action (pp. 17-36). Thousand Oaks, CA: Sage.

Tyler, T. R. (2010). Social justice: Outcome and procedure. International Journal of Psychology, $35,117-125$.

Vera, E. M., \& Speight, S. L. (2003). Multicultural competence, social justice, and counseling psychology: Expanding our roles. The Counseling Psychologist, 31, 253-272. doi: 10.1177/0011000003031003001

Zalaquett, C. P., Foley, P. F., Tillotson, K., Dinsmore, J. A., \& Hof, D. (2008). Multicultural and social justice training for counselor education programs and colleges of education: Rewards and challenges. Journal of Counseling \& Development, 86, 323-329. 